\title{
ATTITUdES OF U.S. AND EUROPEAN MANAGERS TO SUPPLIER SELECTION AND ASSESSMENT AND IMPLICATIONS FOR BUSINESS PERFORMANCE
}

\author{
Vijay R. Kannan \\ Department of Business Administration \\ Utah State University \\ Logan, UT 84322-3510 \\ Tel/Fax: (435) 797-7212/2634 \\ v.kannan@usu.edu \\ Keah Choon Tan \\ Department of Management \\ University of Nevada Las Vegas \\ Las Vegas, NV 89154-6009 \\ Tel/Fax: (702) 895-3873/4370 \\ kctan@unlv.edu
}

October 31, 2002

(This research was sponsored by the APICS E\&R Foundation, and The Supply Chain Council, Inc., Research Grant \#: 99-15) 


\title{
ATTITUdeS OF U.S. AND EUROPEAN MANAGERS TO SUPPLIER SELECTION AND ASSESSMENT AND IMPLICATIONS FOR BUSINESS PERFORMANCE
}

\begin{abstract}
As competition motivates firms to exploit their core competencies, outsourcing takes on greater significance. Increased reliance on supplier capabilities and technologies however increases the impact that supplier selection and assessment can have on the buying firm and in particular, its performance. While prior studies of supply management provide considerable evidence of the criteria used by firms to select and assess suppliers, they provide little insight into the relationships between selection and assessment and the buying firm's performance. This research describes an empirical study of attitudes towards supplier selection and assessment of American and European companies and their impact on business performance. Results illustrate that while both American and European managers consider objective selection and assessment criteria such as cost and price to be more important than subjective criteria such as supplier commitment, it is the more subjective criteria that have a greater impact on firm performance. Moreover, while for American companies there are strong relationships between attitudes towards supply management and performance, similar relationships do not appear to hold for European companies.
\end{abstract}

Key Words: Supply Chain Management, Supplier Selection, Purchasing, Business Performance, Factor Analysis 


\section{Introduction}

Intense competitive pressure to improve delivery performance, quality, and responsiveness, while simultaneously reducing cost, have forced many organizations to re-examine their strategic priorities. For many, this has included recognizing the need to re-focus on core competencies and outsource non-core activities. Not only does this allow firms to downsize and utilize resources more effectively, it allows them to take advantage of the capabilities and technologies of suppliers. In doing so, they can enhance the product development process, improve product quality, reduce product development times, and more rapidly integrate technological breakthroughs of their suppliers into their own products (Monczka et al., 1994, Burt \& Soukup, 1985, Ragatz et al., 1997). Expanding the use of outsourcing however implies that organizations are increasingly reliant on suppliers and must manage them effectively (Prahalad \& Hamel, 1990). For some companies, this has meant reducing and streamlining the supplier base so they can better manage relationships with strategic suppliers (Tully, 1995). For others, it has meant developing cooperative relationships with suppliers (Mason, 1996, Copacino, 1996).

Two key elements in managing the supplier base are supplier selection and supplier assessment. Selecting and assessing suppliers involves both an information dimension and a process dimension. The information dimension, the focus of this study, consists of determining the criteria to be used in selection and assessment decisions. The process dimension involves developing and implementing corresponding decision-making processes. The issue of which criteria to use in selecting suppliers has been examined extensively. A number of studies have empirically examined the relative importance and prevalence of selection criteria for different purchase and product scenarios (Table 1). The conclusion to be drawn from these studies is that while price, quality, delivery reliability, and service are typical determinants of supplier selection, the specific criteria used and their relative importance are highly dependent on the type of purchase being made and the circumstances surrounding the purchase. Moreover, while there may be a tendency to focus on measurable selection criteria such as price, 'soft', intangible criteria such as management compatibility can and should play an important role in selection decisions. In contrast, the issue of how to assess supplier performance has received less attention in the literature. Studies that have 
empirically examined assessment criteria (e.g., Billesbach et al., 1991, Sibley, 1978, Simpson et al., 2002, Walton et al., 1998) however suggest that while cost is the most commonly used metric, quality, delivery, and service are also important assessment metrics.

\begin{tabular}{|c|c|c|}
\hline \multicolumn{2}{|c|}{ Focus of Study } & Study \\
\hline \multirow{7}{*}{$\begin{array}{l}\text { Purchase } \\
\text { Conditions }\end{array}$} & Green Purchasing & Min \& Galle, 1997 \\
\hline & Import Purchases & $\begin{array}{l}\text { Cavusgil \& Yavas, } 1987^{1} \\
\text { Deng \& Wortzel, } 1995^{2} \\
\text { Katsieas \& Leonidou, } 1996^{3} \\
\text { Min and Galle, } 1991^{4} \\
\text { Piercy et al., } 1997^{3}\end{array}$ \\
\hline & Location of Buyer in Supply Chain & Choi and Hartley, 1996 \\
\hline & Purchase Risk & $\begin{array}{l}\text { Cardozo and Cagley, } 1971 \\
\text { Moriarty, } 1983 \\
\text { Tullous and Munson, } 1991 \\
\text { Woodside and Vyas, } 1987 \\
\end{array}$ \\
\hline & Male/Female Buyers & Swift and Gruben, 2000 \\
\hline & Single/Multiple Sources & Swift, 1995 \\
\hline & Strategic Buyer/Supplier Partnerships & Ellram, 1991 \\
\hline \multirow[t]{3}{*}{$\begin{array}{l}\text { Purchase } \\
\text { Type }\end{array}$} & Routine/Non-Routine Orders & $\begin{array}{l}\text { Lehmann \& O’Shaugnessy, 1974, } 1982 \\
\text { Evans, } 1982 \\
\text { Wilson, } 1994 \\
\text { White, } 1978\end{array}$ \\
\hline & Standard/Special Products & Rao and Seshadri, 1996 \\
\hline & Direct/Indirect Materials, Capital Equipment & ASMMA, 1985 \\
\hline $\begin{array}{l}\text { Regional } \\
\text { Purchasing }\end{array}$ & $\begin{array}{l}\text { Chinese Firms } \\
\text { Indian Firms } \\
\text { Japanese Firms } \\
\text { South African Firms }\end{array}$ & $\begin{array}{l}\text { Mummaleni et al., } 1996 \\
\text { Karande et al., } 1999 \\
\text { Hirakubo and Kublin, } 1998 \\
\text { Abratt, } 1986\end{array}$ \\
\hline $\begin{array}{l}\text { Comparative } \\
\text { Practice }\end{array}$ & $\begin{array}{l}\text { U.S. - Japan } \\
\text { U.S. - U.K. } \\
\text { U.S. - South Korea } \\
\text { India - Nigeria }\end{array}$ & $\begin{array}{l}\text { Cusumano and Takeshi, } 1991 \\
\text { Lehmann \& O’Shaugnessy, } 1974 \\
\text { Park and Krishnan, } 2001 \\
\text { Rao and Seshadri, } 1996\end{array}$ \\
\hline
\end{tabular}

${ }^{1}$ Saudi importers $\quad{ }^{2}$ U.S. importers from Asia $\quad{ }^{3}$ U.K. importers from U.S. $\quad{ }^{4}$ U.S. importers

Table 1. Summary of Studies on Supplier Selection Criteria

Given the increasing importance of outsourcing, one would expect that how suppliers are selected and assessed, and in particular, the criteria used to guide these decisions, will impact the buying firm's performance. A greater onus exists on firms to ensure that would be suppliers can create value for the buying organization, and that once selected, supplier performance is consistent with the buying firm's expectations. However, little is known about the relationships between supplier selection and assessment 
and a buying firm's performance. Vonderembse \& Tracey (1999) observed that supplier selection tactics positively impact a buying firm's manufacturing performance. They also demonstrated that high performing companies attach greater importance to key supplier selection criteria such as quality and delivery performance than low performing companies. They did not however attempt to relate supplier selection to broader measures of business performance. The supplier assessment literature makes no reference to studies linking assessment criteria and the performance of the buying firm.

Related to the question of how supplier selection and assessment impact a buying firm's performance is the question of whether common trends exist for firms in different parts of the world. Much of the extant literature on supplier base management is based on the experience of U.S. firms. While a handful of studies have examined supplier base management elsewhere in the world, few have attempted to contrast practices in multi-national settings. None however have examined relationships between supplier selection and assessment and the buying firm's performance. In terms of size, the United States and Europe represent two of the largest economic markets. To date however, only one study has attempted to compare supplier selection in these two markets (Lehmann \& O'Shaugnessy, 1974). This study considered firms in the United Kingdom but did not include firms elsewhere in the region. Moreover, this study was conducted over twenty-five years ago when supply management did not have the same strategic importance as it does today. A study by Billesbach et al., (Bilesbach et al., 1991) compared supplier assessment practices of companies in the U.S. and U.K. Neither study examined relationships with the buying firm's performance. An additional limitation of both studies is that they focused only on specific selection/assessment criteria. No attempts were made to identify and compare underlying dimensions of supplier selection/assessment in the two populations.

Reviewing the pertinent literature reveals that a number of questions remained unanswered. Specifically,

1. Are purchasing and materials managers from the U.S. and Europe similar in their assessment of the importance of specific supplier selection and assessment criteria 
2. What are the underlying dimensions of supplier selection and assessment that managers consider to be important in making purchase decisions and are they the same for managers in the U.S. and Europe

3. How do these dimensions impact the business performance of buying firms, and do they impact performance in a similar way in both the U.S. and Europe

\section{Survey Methodology}

A survey instrument was developed to gather data to address the research questions. A review of the literature, discussions with supply management professionals, and examination of company purchasing manuals identified thirty criteria used to select suppliers and thirteen metrics used to assess supplier performance (Appendix 1). For each, a five-point Likert scale was developed that reflected the extent to which each was considered important to the respondent $(1=$ low, $5=$ high $)$. No consensus exists on how to assess business performance in cross industry studies (Tan et al., 1998). To overcome this limitation, four commonly used measures of business performance that broadly reflect financial, market, and product performance were identified (Appendix 1). Similar to the approach used in Tan et al., (1998), a five-point Likert scale was developed for each measure that sought to determine the performance of the responding firm relative to that of its major competitors $(1=$ low, $5=$ high $)$. The instrument was pretested by thirty senior purchasing and materials managers. As a result, some questions were re-worded to improve content validity and clarity. The revised instrument was sent to senior materials and purchasing managers in the U.S. and Europe. Membership lists from the Institute for Supply Management (ISM) and American Production and Inventory Control Society (APICS) were used to identify subjects from American firms, and the APICS list was used to identify subjects from European firms. Cost considerations precluded soliciting multiple respondents from the same firm to cross validate responses, a common problem in empirical research. However, attempts were made to target senior managers who were in a position to make reasoned assessments of their firm's supply management practices, and of their firm's performance relative to that of competitors.

Five hundred and twenty seven usable surveys were returned, of which four hundred and eleven came from the U.S., and one hundred and sixteen came from Europe. To test for the existence of non- 
response bias in the data, surveys were tested for statistically significant differences in the responses between early and late waves of returned surveys. Late arriving surveys were considered to be representative of non-respondents (Armstrong \& Overton, 1977, Lambert \& Harrington, 1990). Ten survey items were randomly selected in addition to the size of the organizations (number of employees) and annual sales. The data was split into two groups on the basis of return time, and t-tests carried out on mean scores of early and late responses. The tests yielded no statistically significant differences suggesting the absence of non-response bias.

\section{Summary Results}

\section{Respondent Characteristics}

Companies varied in size from 10 to 200,000 employees with a median of 250, and had annual sales of between $\$ 20,000$ and $\$ 30$ billion, with a median of $\$ 30$ million. Fifty three percent of American and fifty eight percent of European firms reported an increase in outsourcing activities for primary materials and component parts over the last three years. Forty nine percent of American and fifty five percent of European firms reported increasing the number of their key or preferred suppliers during the previous three years. While only fifty eight percent of American firms and forty eight percent of European firms reported having strategic alliances with suppliers, there was evidence that the use of strategic alliances is increasing. Seventy eight percent of American firms and eighty two percent of European firms indicated that the number of strategic alliances they were involved in had increased over the previous three years. These observations are consistent with efforts to rationalize the supplier base.

\section{Supplier Selection}

Considerable similarity can be observed in attitudes towards supplier selection for American and European firms. The most important elements for both focus on operational performance, in particular due date performance and commitment to quality, followed by capability (Table 2). Although American firms place statistically greater emphasis on due date performance and commitment to quality than other selection criteria (based on Tukey multiple comparisons, $\alpha=0.05$ ), this is not so for European firms. 
There is also agreement on the least important determinants of supplier selection. Criteria relating to fit between buyer and supplier, in particular cultural and geographical fit, the supplier's size, and use of subcontracting are in both cases the least important items. Only in a few instances are there statistically significant differences between the two samples in terms of the importance placed on specific selection criteria. In each case, it is the American firms that place greater importance on the corresponding selection criterion, specifically (in order of decreasing mean difference) the importance placed on ethical

\begin{tabular}{|c|c|c|}
\hline Supplier Selection Criteria & U.S. & Europe \\
\hline 1. Ability to meet delivery due dates ${ }^{*}$ & $4.62(1)$ & $4.43(2)$ \\
\hline g. Commitment to quality & $4.60(2)$ & $4.48(1)$ \\
\hline e. Technical expertise & $4.25(3)$ & $4.26(3)$ \\
\hline m. Price of materials, parts and services & $4.16(4)$ & $4.02(5)$ \\
\hline p. Honest and frequent communications & $4.11(5)$ & $3.91(7)$ \\
\hline dd. Reserve capacity or the ability to respond to unexpected demand & $4.08(6)$ & $3.96(6)$ \\
\hline f. Industry knowledge & $4.06(7)$ & $4.10(4)$ \\
\hline n. Financial stability and staying power ${ }^{*}$ & $4.03(8)$ & $3.66(12)$ \\
\hline i. Supplier's process capability & $3.98(9)$ & $3.80(9)$ \\
\hline cc. Commitment to continuous improvement in product and process & $3.98(10)$ & $3.82(8)$ \\
\hline b. Ethical standards* & $3.92(11)$ & $3.33(19)$ \\
\hline h. Open to site evaluation* & $3.90(12)$ & $3.54(15)$ \\
\hline k. References/reputation of supplier & $3.86(13)$ & $3.65(13)$ \\
\hline q. Flexible contract terms and conditions & $3.79(14)$ & $3.68(11)$ \\
\hline c. Testing capability & $3.77(15)$ & $3.57(14)$ \\
\hline v. Supplier has strategic importance to your firm & $3.76(16)$ & $3.71(10)$ \\
\hline d. Scope of resources ${ }^{*}$ & $3.69(17)$ & $3.42(17)$ \\
\hline t. Past and current relationship with supplier & $3.63(18)$ & $3.46(16)$ \\
\hline bb. Willingness to integrate supply chain management relationship & $3.39(19)$ & $3.38(18)$ \\
\hline w. Supplier's willingness to share confidential information & $3.37(20)$ & $3.28(20)$ \\
\hline o. Supplier's effort in eliminating waste & $3.29(21)$ & $3.12(23)$ \\
\hline aa. Supplier's ability to make a decent profit for supplying to you & $3.25(22)$ & $3.16(22)$ \\
\hline u. Suppliers' effort in promoting JIT principles & $3.24(23)$ & $3.19(21)$ \\
\hline z. Your annual orders as a percentage of their overall business & $3.15(24)$ & $3.01(24)$ \\
\hline j. Insurance and litigation history ${ }^{*}$ & $3.14(25)$ & $2.86(24)$ \\
\hline r. Geographical compatibility/proximity & $3.07(26)$ & $2.97(25)$ \\
\hline y. Supplier's order entry and invoicing system, including EDI* & $3.03(27)$ & $2.71(28)$ \\
\hline s. Cultural match between the companies & $2.90(28)$ & $2.80(27)$ \\
\hline x. Percentage of supplier's work commonly subcontracted & $2.87(29)$ & $2.68(29)$ \\
\hline a. Company size & $2.67(30)$ & $2.65(30)$ \\
\hline
\end{tabular}

*Indicates statistically significant difference in importance between American and European firms Number in parentheses represent ranking

Table 2. Elements of Supplier Selection 
standards, financial stability, openness to site evaluations, supplier's order entry system, insurance and litigation history, scope of supplier resources, and ability to meet due dates. It is interesting to note that of the seven criteria, four (ethics, finances, openness, and insurance/litigation) refer directly to the character and integrity of the supplier.

\section{Supplier Assessment}

American and European firms are in even closer agreement on the importance of different measures of supplier performance. Not surprisingly, measures of quality, service, on time delivery, and responsiveness consistently rank highest (Table 3). While for American firms the importance of these measures is statistically higher than for others, such delineation is not apparent for European firms. For both, the willingness to share sensitive information and the use of EDI, rank as the least important performance criteria. Mean scores for these two measures are in both cases statistically lower than for those of other measures. For five of the measures of performance, the emphasis placed on them by American firms is statistically greater than for their European counterparts. The five are, in decreasing order of mean difference, correctness of delivery quantity, service level, on time delivery, willingness of supplier to participate in new product development, and quality.

\begin{tabular}{lrc}
\hline \multicolumn{1}{c}{ Supplier Assessment Criteria } & U.S. & Europe \\
\hline a. Quality level* & $4.73(1)$ & $4.45(1)$ \\
b. Service level* & $4.62(2)$ & $4.25(3)$ \\
d. On-time delivery* & $4.57(3)$ & $4.23(4)$ \\
k. Quick response time in case of emergency, problem, or special request & $4.44(4)$ & $4.37(2)$ \\
i. The flexibility to respond to unexpected demand changes & $4.27(5)$ & $4.21(5)$ \\
c. Correct quantity* & $4.15(6)$ & $3.72(8)$ \\
e. Price/cost of product & $4.10(7)$ & $3.93(6)$ \\
l. Willingness to change their products and services to meet your changing needs & $3.88(8)$ & $3.87(7)$ \\
j. Communication skills/systems (phone, fax, email, internet) & $3.79(9)$ & $3.66(9)$ \\
m. Willingness to participate in your firm's new product development \& value analysis* & $3.60(10)$ & $3.31(11)$ \\
h. Presence of certification or other documentation & $3.50(11)$ & $3.55(10)$ \\
g. Willingness to share sensitive information & $3.10(12)$ & $3.12(12)$ \\
f. Use of Electronic Data Interchange (EDI) & $2.69(13)$ & $2.61(13)$ \\
\hline * Indicates statistically significant difference in importance between American and European firms &
\end{tabular}

Table 3. Elements of Supplier Assessment 


\section{Multivariate Analysis}

\section{Content Validity}

Prior to examining relationships between supplier management tactics and performance, reliability and factor analysis were conducted. Reliability analysis provides a measure of the ability of a survey instrument to produce consistent results from one administration to the next, or the degree to which measures are free from random error. A commonly used measure of reliability is Cronbach's $\alpha$ (Cronbach, 1951). Values of $\alpha$ in excess of 0.70 are considered to be indicative of reliable survey scales instruments (Nunnally, 1988). For both American and European firms, supplier selection and assessment scales yielded values of $\alpha$ well in excess of the minimum acceptable value (Table 4).

\begin{tabular}{cccl}
\hline Sample & \multicolumn{1}{c}{ Criterion } & $\alpha$ & \multicolumn{1}{c}{ Notes } \\
\hline U.S. & Supplier Selection & 0.939 & $\begin{array}{l}\text { When items a and m were dropped, the value of } \alpha \text { increased to } \\
\text { 0.941. These items were omitted from subsequent analysis } \\
\text { When item e was dropped, the value of } \alpha \text { increased to } 0.843 . \\
\text { This item was omitted from subsequent analysis }\end{array}$ \\
\hline Supplier Assessment & 0.841 & $\begin{array}{l}\text { When items a and m were dropped, the value of } \alpha \text { increased to } \\
\text { E.941. These items were omitted from subsequent analysis } \\
\text { When item e was dropped, the value of } \alpha \text { increased to } 0.853 . \\
\text { This item was omitted from subsequent analysis }\end{array}$ \\
\hline
\end{tabular}

Table 4. Reliability Analysis

Exploratory factor analysis was conducted to reduce the sets of selection and assessment criteria to smaller numbers of underlying factors. Principal components analysis (eigen values > 1) and varimax rotation were used to obtain interpretable factor matrices. The Bartlett Test of Sphericity and KaiserMeyer-Olkin measure of sampling adequacy were used to validate the use of factor analysis. With few exceptions, items had loadings of at least 0.50 . Those that did not were omitted from subsequent analysis.

Five selection and three assessment factors were obtained from the U.S. sample data. Selection factors reflect a supplier's strategic commitment to the buyer, the suppliers ability to be a good partner, supplier capability, the fit between the buyer and supplier, and the honesty and integrity of the supplier (Table 5). Tukey multiple comparisons $(\alpha=0.05)$ of mean factor scores reveal that ability to be a good 
partner is perceived to be the most important (mean score $=4.17)$, followed by capability $($ mean $=3.94)$, honesty and integrity $($ mean $=3.44)$, strategic commitment of supplier $($ mean $=3.31)$, and buyer/supplier fit $($ mean $=3.20)$. The five factors account for $59 \%$ of total variance in the data. Assessment factors reflect delivery and service quality, supplier responsiveness to changing buyer needs, and information sharing (Table 6). Delivery and service quality yielded the highest mean score (4.52), followed by responsiveness (mean $=4.05$ ) and information sharing (2.89). Differences in mean scores are again statistically significant. The three factors account for $61 \%$ of total variance in the data.

\begin{tabular}{|c|c|c|}
\hline Factor & Scale Item & $\begin{array}{c}\text { Factor } \\
\text { Loadings }\end{array}$ \\
\hline \multirow{3}{*}{ US.SS.1 } & bb. Willingness to integrate supply chain management relationship & .745 \\
\hline & y. Supplier's order entry and invoicing system, including EDI & .624 \\
\hline & v. Supplier has strategic importance to your firm & .623 \\
\hline \multirow{4}{*}{$\begin{array}{c}\text { Strategic } \\
\text { commitment of } \\
\text { supplier to buyer }\end{array}$} & u. Suppliers' effort in promoting JIT principles & 618 \\
\hline & z. Your annual orders as a percentage of their overall business & .570 \\
\hline & aa. Supplier's ability to make a decent profit for supplying to you & .553 \\
\hline & w. Supplier's willingness to share confidential information & .530 \\
\hline \multirow{7}{*}{$\begin{array}{l}\text { Ability to be a } \\
\text { good partner }\end{array}$} & 1. Ability to meet delivery due dates & .716 \\
\hline & p. Honest and frequent communications & 694 \\
\hline & g. Commitment to quality & .638 \\
\hline & cc. Commitment to continuous improvement in product and process & .581 \\
\hline & dd. Reserve capacity or the ability to respond to unexpected demand & .565 \\
\hline & q. Flexible contract terms and conditions & .557 \\
\hline & n. Financial stability and staying power & .540 \\
\hline \multirow{4}{*}{$\begin{array}{c}\text { US.SS.3 } \\
\text { Capability }\end{array}$} & e. $\quad$ Technical expertise & .733 \\
\hline & f. Industry knowledge & .732 \\
\hline & d. Scope of resources & .710 \\
\hline & c. Testing capability & .645 \\
\hline US.SS.4 & r. Geographical compatibility/proximity & .729 \\
\hline \multirow{2}{*}{$\begin{array}{c}\text { Buyer/Supplier } \\
\text { Fit }\end{array}$} & s. Cultural match between the companies & .676 \\
\hline & t. Past and current relationship with supplier & .581 \\
\hline \multirow{3}{*}{$\begin{array}{c}\text { US.SS.5 } \\
\text { Honesty and } \\
\text { integrity }\end{array}$} & j. Insurance and litigation history & .698 \\
\hline & h. Open to site evaluation & .535 \\
\hline & o. Supplier's effort in eliminating waste & .532 \\
\hline
\end{tabular}

Table 5. Factor Analysis: Supplier Selection - U.S. Sample

Factor analysis of the European sample data yielded seven selection and three assessment factors. Two of the selection factors (Table 7), supplier's strategic orientation to operations (EU.SS.1), and 


\begin{tabular}{|c|c|c|}
\hline Factor & Scale Item & $\begin{array}{c}\text { Factor } \\
\text { Loadings }\end{array}$ \\
\hline \multirow{4}{*}{$\begin{array}{c}\text { US.SE. } 1 \text { Delivery } \\
\text { and Service } \\
\text { Quality }\end{array}$} & b. Service level & .804 \\
\hline & d. On-time delivery & .738 \\
\hline & a. Quality level & .726 \\
\hline & c. Correct quantity & .625 \\
\hline \multirow{4}{*}{$\begin{array}{c}\text { US.SE.2 } \\
\text { Responsiveness }\end{array}$} & 1. Willingness to change products, services to meet your changing needs & .816 \\
\hline & k. Quick response time in case of emergency, problem, or special request & .725 \\
\hline & m. Willingness to participate in new product development, value analysis & 669 \\
\hline & i. The flexibility to respond to unexpected demand changes & .662 \\
\hline \multirow{2}{*}{$\begin{array}{c}\text { US.SE.3 } \\
\text { Information } \\
\text { Sharing }\end{array}$} & f. Use of Electronic Data Interchange (EDI) & .844 \\
\hline & g. Willingness to share sensitive information & .793 \\
\hline
\end{tabular}

Table 6. Factor Analysis: Supplier Assessment - U.S. Sample

\begin{tabular}{|c|c|c|}
\hline Factor & Scale Item & $\begin{array}{c}\text { Factor } \\
\text { Loadings }\end{array}$ \\
\hline & bb. Willingness to integrate supply chain management relationship & .847 \\
\hline EU.SS.1 & u. Suppliers' effort in promoting JIT principles & .769 \\
\hline Strategic & cc. Commitment to continuous improvement in product and process & .718 \\
\hline Commitment to & y. Supplier's order entry and invoicing system, including EDI & .635 \\
\hline \multirow[t]{2}{*}{ Operations } & o. Supplier's effort in eliminating waste & .611 \\
\hline & aa. Supplier's ability to make a decent profit for supplying to you & .535 \\
\hline \multirow{3}{*}{$\begin{array}{c}\text { EU.SS.2 } \\
\text { Capability }\end{array}$} & e. Technical expertise & .835 \\
\hline & f. Industry knowledge & .765 \\
\hline & g. Commitment to quality & .590 \\
\hline \multirow{4}{*}{$\begin{array}{c}\text { EU.SS.3 } \\
\text { Openness and } \\
\text { Stability }\end{array}$} & h. Open to site evaluation & .703 \\
\hline & j. Insurance and litigation history & .645 \\
\hline & dd. Reserve capacity or the ability to respond to unexpected demand & .558 \\
\hline & n. Financial stability and staying power & .534 \\
\hline \multirow{4}{*}{$\begin{array}{c}\text { EU.SS.4 } \\
\text { Supplier } \\
\text { Reputation }\end{array}$} & t. $\quad$ Past and current relationship with supplier & .812 \\
\hline & k. References/reputation of supplier & .607 \\
\hline & v. Supplier has strategic importance to your firm & .572 \\
\hline & b. Ethical standards & .535 \\
\hline \multirow{2}{*}{$\begin{array}{c}\text { EU.SS.5 } \\
\text { Order Dynamics }\end{array}$} & x. Percentage of supplier's work commonly subcontracted & .737 \\
\hline & z. Your annual orders as a percentage of their overall business & .674 \\
\hline \multirow{2}{*}{$\begin{array}{c}\text { EU.SS.6 } \\
\text { Communication } \\
\text { and delivery }\end{array}$} & 1. Ability to meet delivery due dates & .824 \\
\hline & p. Honest and frequent communications & .630 \\
\hline \multirow{2}{*}{$\begin{array}{c}\text { EU.SS.7 } \\
\text { Contractual and } \\
\text { cultural fit }\end{array}$} & q. Flexible contract terms and conditions & .662 \\
\hline & s. Cultural match between the companies & .610 \\
\hline
\end{tabular}

Table 7. Factor Analysis: Supplier Selection - European Sample 
capability (EU.SS.2), are similar to factors extracted from the U.S. sample (US.SS.1 and US.SS.3) respectively. An important distinction however is that factor US.SS.1 is broader than factor EU.SS.1, reflecting not only the supplier's strategic commitment to operations but incorporating attributes of the buyer/supplier relationship. Factor EU.SS.3, openness and stability, is similar to factor US.SS.5. Both reflect the openness of the supplier and its long-term stability. Factors EU.SS.4, supplier reputation, and EU.SS.6, communication and delivery, when taken together, address the ability of the supplier to be a reliable partner. While similar to factor US.SS.2, it is clear that for European firms, supplier reputation is a distinct factor. The remaining factors loosely reflect the importance of the buyer and subcontractors to the supplier, and the fit between buyer and supplier regarding contract terms and culture.

Factor means indicate that capability (mean score $=4.28$ ) and communication and delivery (mean $=4.17)$ are considered to be the most important selection factors. Supplier reputation $($ mean $=3.53)$ and openness and stability (mean $=3.51$ ) are considered to be of equal importance, as are contractual/cultural fit $($ mean $=3.24)$ and strategic commitment to operations $(3.23)$. Order dynamics is considered to be the least important factor (mean $=2.84$ ). These results are consistent with those for American firms to the extent that capability and the ability of the supplier to service the buying firm's needs are considered to be of greatest importance. It is important to note however that in both cases, the strategic orientation of the supplier to operations/customers is considered to be of only moderate importance, as is the compatibility of the buyer with the supplier. The seven factors account for 65 percent of total variance in the data.

Two assessment factors (Table 8), delivery and service quality, and information sharing, are similar to factors extracted from the U.S. sample. The third, flexibility and certification, parallels factor US.SE.2, responsiveness, but does not reflect supplier willingness to participate in the buying firm's product development activities. Mean factor scores indicate that delivery and service quality (mean = 4.06 ) and the flexibility of the supplier (mean $=4.05$ ) are the most important followed by information sharing $($ mean $=2.86$ ). This parallels the results for American firms. The three factors account for $63 \%$ of total variance. 


\begin{tabular}{cllc}
\hline Factor & & \multicolumn{1}{c}{ Scale Item } & $\begin{array}{c}\text { Factor } \\
\text { Loadings }\end{array}$ \\
& & & .772 \\
$E U . S E .1$ & b. & Service level & On-time delivery \\
Delivery and & a. & Quality level & .772 \\
Service Quality & j. & Communication skills/systems (phone, fax, email, internet) & .747 \\
& c. & Correct quantity & .623 \\
\hline$E U . S E .2$ & f. & Use of Electronic Data Interchange (EDI) & .572 \\
Information & g. & Willingness to share sensitive information & .893 \\
Sharing & i. & & .638 \\
\hline$E U . S E .3$ & i. & The flexibility to respond to unexpected demand changes & .802 \\
Flexibility and & k. & Quick response time in case of emergency, problem, or special request & .751 \\
Certification & h. & Presence of certification or other documentation & .536 \\
\hline
\end{tabular}

Table 8. Factor Analysis: Supplier Assessment - European Sample

\section{Correlation Analysis}

Correlation analysis reveals distinct differences in the impact on business performance of attitudes to selection and assessment of American and European firms. For American firms, ability to be a good partner, the most important selection factor, correlates positively with only product quality (Table 9) while capability, which ranks second in importance, correlates positively with both product quality and competitive position. In contrast, honesty and integrity, which ranks third in importance, correlates positively with all performance measures with the exception of market share, while strategic commitment of the supplier, which ranks fourth in importance, correlates positively with all performance measures. Of the assessment factors, delivery and service quality correlate positively with both product quality and competitive position, while responsiveness correlates positively with product quality and return on assets. Information sharing, the least commonly used assessment criterion, correlates positively with all four performance measures. In contrast to the many significant positive relationships between selection and assessment and performance for American firms, there is only one significant positive correlation for European firms, between selection based on supplier capability and product quality. 


\begin{tabular}{|c|c|c|c|c|c|}
\hline \multirow{3}{*}{ Sample } & \multirow{3}{*}{ Factor } & \multicolumn{4}{|c|}{ Firm Performance } \\
\hline & & \multicolumn{4}{|c|}{ Market Return on Product Competitive } \\
\hline & & Share & Assets & Quality & Position \\
\hline \multirow{8}{*}{ U.S. } & US.SS.1: Strategic Commitment of supplier to buyer & $.161^{*}$ & $.190^{*}$ & $.134^{*}$ & $.153^{*}$ \\
\hline & US.SS.2: Ability to be a good partner & -.066 & .082 & $.152^{*}$ & .081 \\
\hline & US.SS.3: Capability & .072 & .097 & $.180^{*}$ & $.164^{*}$ \\
\hline & US.SS.4: Buyer/Supplier Fit & -.029 & .040 & -.008 & .050 \\
\hline & US.SS.5: Honesty and Integrity & .084 & $.137^{*}$ & $.153^{*}$ & $.104^{*}$ \\
\hline & US.SE.1: Delivery and Service Quality & .099 & .082 & $.218^{*}$ & $.167^{*}$ \\
\hline & US.SE.2: Responsiveness & -.026 & $.102^{*}$ & $.152^{*}$ & .070 \\
\hline & US.SE.3: Information Sharing & $.162^{*}$ & $.155^{*}$ & $.133^{*}$ & $.190^{*}$ \\
\hline \multirow{10}{*}{ Europe } & EU.SS.1: Strategic Commitment to Operations & .150 & .078 & .069 & .138 \\
\hline & EU.SS.2: Capability & .098 & -.025 & $.208^{*}$ & .080 \\
\hline & EU.SS.3: Openness and Stability & .077 & .042 & .022 & -.103 \\
\hline & EU.SS.4: Supplier Reputation & .003 & -.012 & .156 & -.100 \\
\hline & EU.SS.5: Order Dynamics & .165 & .204 & -.100 & .027 \\
\hline & EU.SS.6: Communication and Delivery & -.041 & -.082 & -.058 & -.075 \\
\hline & EU.SS.7: Contractual and Cultural Fit & -.072 & -.016 & -.004 & .058 \\
\hline & EU.SE.1: Delivery and Service Quality & -.043 & -.005 & .118 & .001 \\
\hline & EU.SE.2: Information Sharing & .092 & -.069 & .086 & .136 \\
\hline & EU.SE.3: Flexibility and Certification & .136 & -.017 & .190 & .124 \\
\hline
\end{tabular}

* indicates significance at $\alpha=0.05$ level

Table 9. Correlation Analysis

\section{Discussion}

For American firms, it is apparent that there is a relationship between attitudes to supplier management and performance. However, it is equally clear that while operational considerations dominate attitudes, strategic considerations have the greater impact. The two selection factors that yielded the highest mean scores, ability to be a good partner and capability, correlate positively with one and two measures of performance respectively, product quality in the case of partnering, and product quality and competitive position in the case of capability. Suppliers who consider it important to work with their customers to meet their needs and who have the ability to meet these needs with high quality products, contribute to the quality of the buying firm's products. However, product quality and competitive position may reflect only a buying firm's short-term performance. For the benefits of collaboration to reflect itself in a buying firm's long term performance, as measured by return on assets and market share, a greater, strategic commitment to the customer is required from the supplier. In addition, it requires a willingness on the part of the supplier to open itself up to the customer, and an established record as a supplier of 
integrity. If firms are to enter into long-term alliances with suppliers, they are going to require historical rather than just recent evidence of the supplier's record and performance. Examining the relationship between supplier assessment and performance underscores this. While delivery and service quality impact product quality and the ability of the buying firm to meet the expectations of its customers, long-term success requires suppliers willing to respond to its customers changing needs. More importantly, it requires close cooperation, and by implication, significant information flow, between the buying firm and its suppliers. Despite the evidence that information sharing has the broadest correlation with a buying firm's performance, it is considered the least important dimension of supplier assessment. This may be a result of continued resistance of buyers and suppliers to share crucial information, or it may be the result of uncertainty in how to measure the extent and quality of information sharing. Either way, it is clear that recognizing the value of shared information and following through with corresponding action, can significantly impact the long-term success of the buying firm.

Why attitudes towards supplier management have more limited impact on the performance of European firms is not clear. One can speculate on a number of possible reasons. The more fragmented European market may make it more difficult for European respondents to make judgments regarding relative performance than American respondents. It may also make it more difficult to establish the supply chain relationships that enhance performance. There may be greater awareness on the part of American firms regarding the impact of supplier management on their own performance, which has in turn influenced their supply management tactics. Competitive pressures faced by American firms may be responsible for elevating their supply management practices to a level of sophistication that has not yet been attained by European firms. It is also possible that the size of the European sample may have contributed to this outcome. Only further study will yield a definitive answer.

The results raise important issues regarding the distinction between 'hard' and 'soft' supplier selection criteria. While the evidence suggests that for both American and European firms 'hard' selection, and for that matter assessment criteria, are viewed as being more important, it is clear that attitudes towards 'soft' criteria have, at least for American firms, broader impact. Moreover, although 
Ellram (1990) showed that 'soft' criteria are important in the context of strategic buyer/supplier partnerships, the results here suggest they can have an impact on the buying firm's performance regardless of whether the buyer/supplier relationship is strategic.

\section{Conclusions}

To the extent that they place comparable levels of importance on various supplier selection and assessment tactics, American and European firms are similar in their attitudes to supply management. They are also similar in that they demonstrate a preference for hard, measurable, objective selection and assessment criteria, and are somewhat averse to more subjective criteria, despite the fact that they have a greater impact on their firm's long-term performance. The results suggest the need for organizations to reexamine their objectives in procurement planning. Strategic alignment with suppliers not only directly impacts performance as suggested by the results, but also does so indirectly. Addressing delivery and quality problems for example is easier if there is a relationship between a buying firm and its supplier, and clearly articulated and mutually accepted expectations. Developing relationships however takes considerable effort, and requires participants to assume a level of trust and reliance in their partners that may reflect a significant departure from established norms. Suppliers can however no longer be viewed as independent entities to be dealt with at arms length, but as extensions of the buying firm itself.

\section{References}

ASMMA (American Supply and Machinery Manufacturers Association) (1985), An evaluation of industrial purchasing and distribution trends: A research investigation, Cleveland.

Abratt, R., (1986), “Industrial buying in high tech markets”, Industrial Marketing Management, Vol. 15 No. 4, pp. 293-298.

Armstrong, J. S., Overton, T.S. (1977), "Estimating non-response bias in mail surveys", Journal of Marketing Research, Vol. 14 No. 3, pp. 396-402.

Billesbach, T.J., Harrison, A., Croom-Morgan, S. (1991), "Supplier performance measures and practices in JIT companies in the U.S. and U.K", International Journal of Purchasing and Materials Management, Vol. 21 No. 4, pp. 24-28.

Burt, D.N., Soukup, W.R. (1985), "Purchasing's role in new product development", Harvard Business Review, Vol. 63 No. 5, pp.89-97. 
Cardozo, R.N., Cagley, J.W., (1971), "Experimental Study of Industrial Buyer Behavior”, Journal of Marketing Research, Vol. 8, pp. 329-334.

Cavusgil, S.T., Yavas, U., (1987), "Supplier selection in international markets: A study of Saudi importers", Industrial Marketing and Purchasing, Vol. 2 No. 2, pp. 19-28.

Choi, T.Y., Hartley, J.L. (1996), “An exploration of supplier selection practices across the supply chain”, Journal of Operations Management, Vol. 14 No. 4, pp. 333-343.

Copacino, W.C. (1996), “Seven supply chain principles”, Traffic Management, Vol. 35 No. 1, p.60.

Cronbach, L.J. (1951), "Coefficient alpha and the internal structure of tests", Psychometrika, Vol. 16, pp. 297-334.

Cusumano, M.A., Takeishi, A., (1991), "Supplier relations and management: A survey of Japanese, Japanese-transplant, and U.S. auto plants", Strategic Management Journal, Vol. 12 No. 8, pp. 563-588.

Deng, S., Wortzel, L.H. (1995), "Importer purchase behavior: Guidelines for Asian exporters", Journal of Business Research, Vol. 32 No. 1, pp. 41-47.

Ellram, L.M. (1991), "The supplier selection decision in strategic partnerships", Journal of Purchasing and Materials Management, Vol. 20 No. 4, pp. 8-14.

Evans, R.H. (1982), "Product involvement and industrial buying", Journal of Purchasing and Materials Management, Vol. 18 No. 2, pp. 23-28.

Hirakubo, N., Kublin, M., (1998), "The relative importance of supplier selection criteria: The case of electronic components procurement in Japan", International Journal of Purchasing and Materials Management, Vol. 34 No. 2, pp. 19-24.

Karande, K., Shankarmahesh, M.N., Rao, C.P. (1999), "Marketing to public and private sector companies in emerging countries: A study of Indian purchasing managers", Journal of International Marketing, Vol. 7 No. 3, pp. 64-83.

Katsikeas, C.S., Leonidou, L.C. (1996), "International supplier selection: The relevance of import dependence", Journal of Global Marketing, Vol. 9 No. 3, pp. 23-45.

Lambert, D. M., Harrington, T.C. (1990), "Measuring non-response bias in mail surveys", Journal of Business Logistics, Vol. 11 No. 2, pp. 5-25.

Lehmann, D.R., O'Shaughnessy, J. (1982), "Decision criteria used in buying different categories of products", Journal of Purchasing and Materials Management, Vol. 18 No. 1, pp. 9-14.

Lehmann, D.R., O'Shaughnessy, J. (1974), "Difference in attribute importance for different industrial products", Journal of Marketing, Vol. 38, pp. 36-42.

Mason, T. (1996), “Getting your suppliers on the team”, Logistics Focus, Vol. 4 No 1, pp. 10-12.

Min, H., Galle, W.P. (1997), "Green purchasing strategies: Trends and implications", International Journal of Purchasing and Materials Management, Vol. 33 No. 3, pp. 10-17.

Monczka, R. M., Trent, R. J., Callahan, T. J. (1994), "Supply base strategies to maximize supplier performance", International Journal of Physical Distribution and Logistics, Vol. 24 No. 1, pp. 42-54.

Moriarty, R.T., (1983), Industrial Buying Behavior, Lexington Books, Lexington.

Mummalaneni, V., Dubas, K. M., Chao, C. (1996), "Chinese purchasing managers' preferences and tradeoffs in supplier selection and performance evaluation", Industrial Marketing Management, Vol. 25 No. 2, pp. 115-124.

Nunnally, J. (1988), Psychometric Theory, McGraw-Hill, New York. 
Park, D., Krishnan, H.A., (2001), “Understanding supplier selection practices: Differences between U.S. and Korean executives", Thunderbird International Business Review, Vol. 43 No. 2, pp. 243-255

Piercy, N.F., Katsikeas, C.S., Cravens, D.W. (1997), "Examining the role of buyer-seller relationships in export performance", Journal of World Business, Vol. 32 No. 2, pp. 73-86.

Prahalad, C. K., Hamel, G. (1990), "The core competence of the corporation", Harvard Business Review, Vol. 68 No 3, pp. 79-91.

Ragatz, G.L., Handfield, R.B., Scannell, T.V. (1997), "Success factors for integrating suppliers into new product development", Journal of Production and Innovation Management, Vol. 14 No. 3, pp. 190-202.

Rao, C.P., Seshadri, S., (1996), "Industrial buyers' expectations of supplier attributes across developing countries: Implications for marketing strategies", The International Executive, Vol. 38 No. 5, pp. 671689.

Sibley, S.D., (1978) "How interfacing departments rate vendors", Journal of Purchasing and Materials Management, Vol. 14 No. 2, pp. 30-34.

Simpson, P.M., Siguaw, J.A., White, S.C., (2002), "Measuring the performance of suppliers: An analysis of evaluation processes", Journal of Supply Chain Management, Vol. 38 No. 1, pp. 29-41.

Swift, C.O. (1995), "Preferences for single sourcing and supplier selection criteria", Journal of Business Research, Vol. 32 No. 2, pp. 105-111.

Swift, C.O., Gruben, K.H., (2000), "Gender differences in weighting of supplier selection criteria", Journal of Managerial Issues, Vol. 12 No. 4, pp. 502-512.

Tan, K.C., Kannan, V.R., Handfield, R.B. (1998), "Supply chain management: Supplier performance and firm performance", International Journal of Purchasing and Materials Management, Vol. 34 No. 3, pp. $2-9$.

Tullous, R., Munson, J.M., (1991), “Tradeoffs under uncertainty: Implications for industrial purchasers", International Journal of Purchasing and Materials Management, Vol. 27 No. 3, pp. 24-31.

Tully, S. (1995), "Purchasing’s new muscle”, Fortune, Vol. 20, p. 76.

Vonderembse, M.A., Tracey, M. (1999), "The impact of supplier selection criteria and supplier involvement on manufacturing performance", Journal of Supply Chain Management, Vol. 35 No. 3, pp. 33-39.

Walton, S.V., Handfield, R.B., Melnyk, S.A. (1998), "The green supply chain: Integrating suppliers into environmental management processes", International Journal of Purchasing and Materials Management, Vol. 34 No. 1, pp. 2-11.

White, P.D. (1978), Decision making in the purchasing process: A report, AMACOM, New York.

Wilson, E. (1994), "The relative importance of supplier selection criteria: A review and update", International Journal of Purchasing and Materials Management, Vol. 30 No. 3, pp. 35-41.

Woodside, A.G., Vyas, N., (1987), Industrial Purchasing Strategies, Lexington Books, Lexington 
1. How important are the following factors when selecting a key/preferred supplier for your organization?

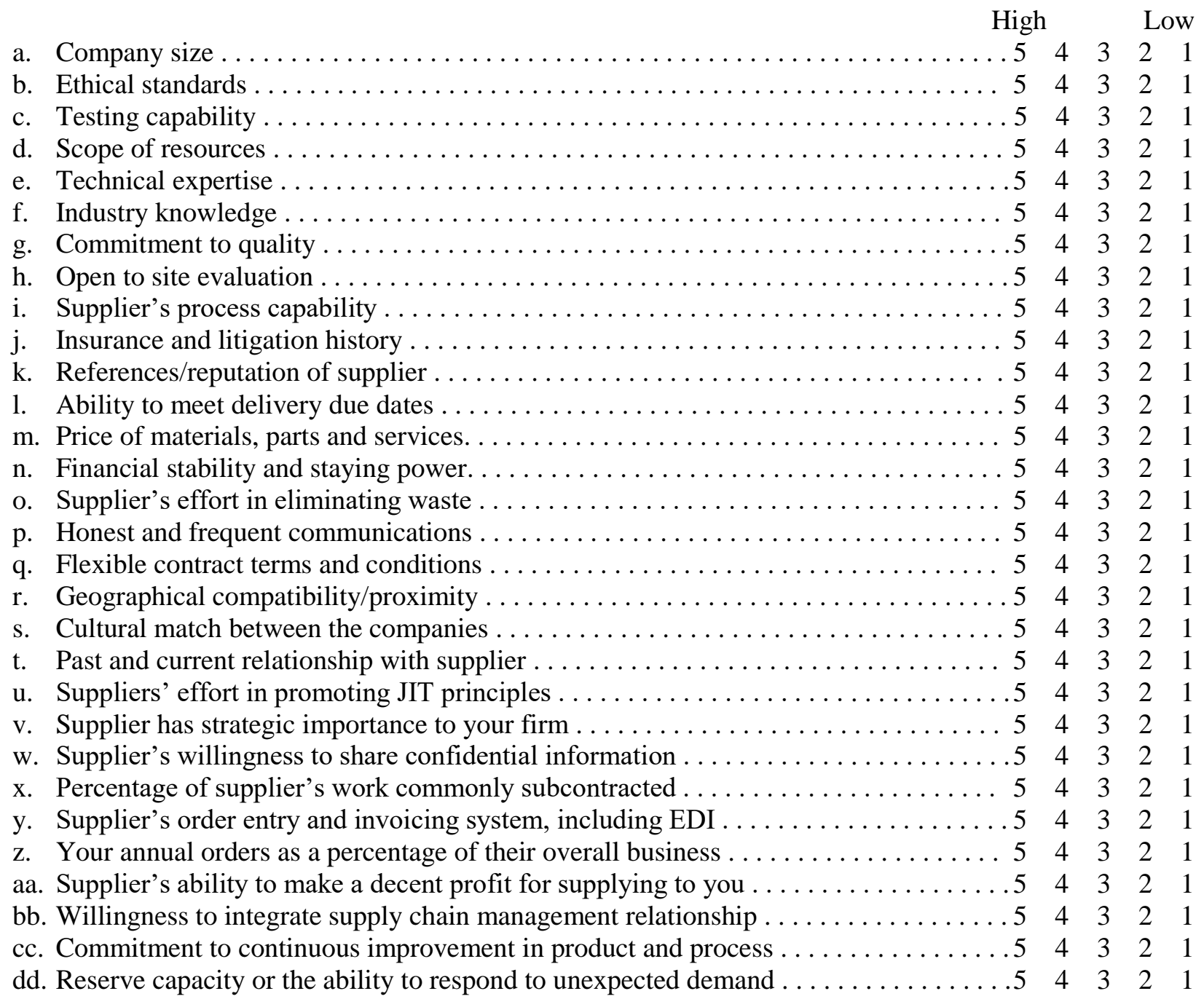

2. How important are the following issues when evaluating your key/preferred suppliers' performance?

\begin{tabular}{|c|c|c|c|}
\hline High & & & Low \\
\hline a. Quality level & 4 & & \\
\hline b. Service level. & 4 & & \\
\hline c. Correct quantity & 4 & & \\
\hline d. On-time delivery . & 4 & & 2 \\
\hline e. Price/cost of product. & 4 & & 2 \\
\hline f. Use of Electronic Data Interchange (EDI) & 4 & & 2 \\
\hline g. Willingness to share sensitive information . & 4 & & 2 \\
\hline of certification or other documentation & 4 & & 2 \\
\hline spond to unexpected demand changes $\ldots \ldots \ldots \ldots \ldots \ldots \ldots$ & 4 & & 2 \\
\hline on skills/systems (phone, fax, email, internet) $\ldots \ldots \ldots \ldots \ldots \ldots 5$ & 4 & & 2 \\
\hline k. Quick response time in case of emergency, problem, or special request .... & 4 & & 2 \\
\hline 1. Willingness to change their products and services to meet your changing needs . & 4 & & 2 \\
\hline n. Willingness to participate in your firm's new product development and value analysis 5 & 4 & & \\
\hline
\end{tabular}


3. Indicate your firm's performance compared to that of major industrial competitors in terms of

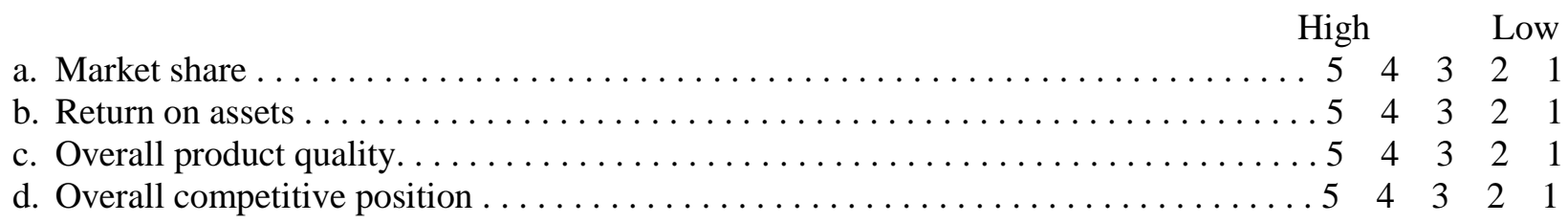

